\title{
Colloid Formation at Waste Plume Fronts
}

JiAmin WAN $^{1 *}$, Tetsu K. Tokunaga ${ }^{1}$, Eduardo SAiZ ${ }^{2}$, Joern T. LARSEN ${ }^{1}$, Zuoping Zheng ${ }^{1}$, AND REX A. COUTURE ${ }^{3}$

1. Earth Sciences Division, Lawrence Berkeley National Laboratory, Berkeley, CA 94720

2. Material Science Division, Lawrence Berkeley National Laboratory, Berkeley, CA 94720

3. Dept. of Earth and Planetary Sciences, Washington University, St. Louis, MO 63130

Highly saline and caustic tank waste solutions containing radionuclides and toxic metals have leaked into sediments at U. S. Department of Energy (DOE) facilities such as the Hanford Site (Washington State). Colloid transport is frequently invoked to explain migration of radionuclides and metals in the subsurface. To understand colloid formation during interactions between highly reactive fluids and sediments and its impact on contaminant transport, we simulated tank waste solution (TWS) leakage processes in laboratory columns at ambient and elevated $\left(70^{\circ} \mathrm{C}\right)$ temperatures. We found that maximum formation of mobile colloids occurred at the plume fronts (hundreds to thousands times higher than within the plume bodies or during later leaching). Concentrations of suspended solids were as high as $\mathbf{3}$ mass $\%$, and their particle-sizes ranged from tens of $\mathrm{nm}$ to a few $\boldsymbol{\mu m}$. Colloid chemical composition and mineralogy depended on temperature. During infiltration of the leaked high $\mathrm{Na}^{+}$waste solution, rapid and completed $\mathrm{Na}^{+}$ replacement of exchangeable $\mathrm{Ca}^{2+}$ and $\mathrm{Mg}^{2+}$ from the sediment caused accumulation of these divalent cations at the moving plume front. Precipitation of supersaturated $\mathrm{Ca}^{2+} / \mathrm{Mg}^{2+}$-bearing minerals caused dramatic $\mathrm{pH}$ reduction at the plume front. In turn, the reduced $\mathrm{pH}$ caused precipitation of other minerals. This understanding can help predict the behavior of contaminant trace elements carried by the tank waste solutions, and could not have been obtained through conventional batch studies. 


\section{Introduction}

Leakage of radioactive wastes and toxic metals into the subsurface has been identified at various DOE facilities (1). At the Hanford Site in Washington State, about $2 \times 10^{5} \mathrm{~m}^{3}$ of high-level radioactive and hazardous wastes are stored in 177 underground tanks, including 149 single-shell tanks. Over time, 67 of the single-shell tanks developed leaks (2). Radionuclides and other contaminants have been found at elevated concentrations in the vadose zone and groundwater beneath the single-shell tank farms (3). The nature of pathways and mechanisms responsible for contaminant transport are not yet fully known, but such understanding is needed for future risk assessment and remediation.

Besides carrying fission products, some of the tank waste solutions were very saline and caustic, containing high concentrations of sodium, nitrate, and aluminum (4-6). Heat released from radioactive decay caused tank waste solutions to boil, and temperatures in underlying sediments were sustained above ambient levels. Because of their extreme chemical-physical conditions, leakage of these tank solutions into the sediments resulted in dissolution of primary minerals and precipitation of secondary minerals. Formation of secondary colloidal phases could have become associated with contaminants from the tank liquids through co-precipitation and adsorption. Subsequent colloid transport might have contributed to the deep migration of contaminants $(7,8)$. Under the DOE's initiative on cleanup of the Hanford Site, recent studies have resulted in a variety of findings relevant to contaminant transport, including identifying the mechanisms for sorption of $\mathrm{Cs}^{+}$in sediments $(9,10)$, the formation of cancrinite as a secondary mineral phase $(11,12)$, the geochemical evolution of waste plumes $(13,14)$, the effect of cation exchange on $\mathrm{Cs}^{+}$ sorption $(15,16)$, and the effect of colloids on $\mathrm{Cs}^{+}$transport (17).

In recent studies $(13,14)$, we showed that three distinct zones occur within active saline-caustic waste plumes; the silicate dissolution zone, neutralization zone, and plume front. The plume front is the moving boundary between invading tank waste solution and displaced uncontaminated pore waters. In this paper we report findings on colloid 
formation at the plume front obtained from our laboratory simulations of the tank waste leakage process.

\section{Experimental Section}

Sediment. Hanford Formation "coarse sand", a glaciofluvial sediment collected from the 200 East Area, was used in our experiments. The Hanford Formation comprises about $85 \%$ of the vadose zone of the site. The 200 East and 200 West Areas are the locations housing high-level waste tanks at the Hanford Site. The major mineral components are presented in Table 1. The median grain-size is $350 \mu \mathrm{m}$, and average grain density is 2.77 $\mathrm{Mg} \mathrm{m}^{-3}$. The chemical composition of a water extract from this sediment (water to soil mass ratio $=1: 1$, at $21^{\circ} \mathrm{C}$ for 24 hours) is presented in Table 2.

Table 1. Mineral composition of the Hanford coarse sand

\begin{tabular}{|l|l|l|l|l|l|}
\hline & $\%$ & Main Minerals & $\%$ & Clay minerals & $\%$ \\
\hline sand & 93 & quartz & 55 & illite & 40 \\
silt & 6 & K-feldspar & 25 & smectite & 20 \\
clay & 1 & Na-feldspar & 15 & mixed- illite and smectite & 20 \\
& & calcium carbonate & 1 & kaolinite & 20 \\
& & others & $<4$ & & \\
\hline
\end{tabular}

From Serne et al. (18)

Table 2. Chemical composition of water extract from the Hanford coarse sand

\begin{tabular}{|l|l|l|l|l|l|l|l|l|}
\hline Element & $\mathrm{Na}$ & $\mathrm{K}$ & $\mathrm{Ca}$ & $\mathrm{Mg}$ & $\mathrm{Cl}^{-}$ & $\mathrm{SO}_{4}^{-2}$ & $\mathrm{HCO}_{3}^{-}$ & $\mathrm{pH}$ \\
\hline $\mathrm{mM}$ & 1.85 & 0.31 & 0.53 & 0.18 & 0.75 & 0.76 & 1.3 & 8.3 \\
\hline
\end{tabular}

Water to soil mass ratio $=1: 1$ 
Synthetic Tank Waste Solution (TWS). The highly saline-caustic tank waste solutions at Hanford were generated from past $\mathrm{Pu}$ and $\mathrm{U}$ processing, in which aluminum nitrate solutions were used to dissolve $\mathrm{Pu}$ and $\mathrm{U}$ from spent fuel. After extracting actinides, the residual acidic solution was treated with $\mathrm{NaOH}$ to keep $\mathrm{Al}$ in solution. The waste solution was then pumped into underground tanks for storage. A typical fresh waste solution was a $4 \mathrm{M}$ sodium-nitrate-nitrite-aluminate-hydroxide solution (4). Upon self-boiling while in subsurface waste tanks, the original solutions became more concentrated and formed salt cakes. Because different tanks leaked at different times and over different periods, the precise chemical compositions of waste solutions at the times of leaking are unknown. Agnew et al. (4) estimated compositions of tank supernatants based on their comprehensive survey (Table 3). The synthetic tank waste solution (TWS) used in this study was based on the directly measured composition of single shell tank SX-111 (Table 3), which is believed to be fairly representative of leaked TWS from the SX tank farm. This synthetic TWS is within the middle range of Agnew's (4) estimated composition of tank supernatant solutions. Radionuclides were not included in our synthetic TWS, because this study focused on the behavior of the major elements. All salts added to the synthetic TWS were completely dissolved within hours of stirring at room temperature, resulting in a solution density of $1.37 \mathrm{Mg} \mathrm{m}^{-3}$. The solution was filtered $(0.45 \mu \mathrm{m})$ before use.

Table 3. Chemical composition of tank waste solutions

\begin{tabular}{|c|c|c|c|}
\hline Component & Our synthetic TWS & Measured SX-111 & Agnew's estimate \\
\hline & (Molar) & (Molar) & (Molar) \\
\hline $\mathrm{Al}$ & 0.805 & 0.805 & 0.7 to 1.9 \\
\hline $\mathrm{CO}_{3}^{-2}$ & 0.168 & 0.168 & 0.2 to 0.3 \\
\hline $\mathrm{OH}^{-}$ & 1.47 & 1.47 & 3 to 8.5 \\
\hline
\end{tabular}




\begin{tabular}{|c|c|c|c|}
\hline $\mathrm{NO}_{3}^{-}$ & 4.72 & 4.72 & 2.3 to 6.3 \\
\hline $\mathrm{NO}_{2}^{-}$ & 0.84 & 0.84 & 1 to 2.9 \\
\hline $\mathrm{SO}_{4}^{-2}$ & 0.06 & 0.06 & 0.1 to 0.3 \\
\hline $\mathrm{Na}^{+}$ & 8.05 & 8.05 & 5 to 14 \\
\hline $\mathrm{pH}$ & $14.1\left(21^{\circ} \mathrm{C}\right)$ & & $>14$ \\
\hline
\end{tabular}

Column Method. The Teflon columns used to contain Hanford sediments were of two lengths, 50 and $250 \mathrm{~mm}$, with an inner diameter of $38 \mathrm{~mm}$. Both end caps of each column had polypropylene screens (105 $\mu \mathrm{m}$ mesh) to support the sediment and yet allow the transport of suspended particles. Moistened sediments (water 7\% by mass) were packed into columns to an equivalent dry bulk density of $1.65( \pm 0.05) \mathrm{Mg} \mathrm{m}^{-3}$, to represent the initial partially saturated vadose zone (about $30 \%$ saturation). Pore volumes for the 50 and $250 \mathrm{~mm}$ columns were 22.9 and $115 \mathrm{~mL}$, respectively. To avoid gravity-induced flow fingering, solutions were injected upwards from the bottom of vertically oriented columns. Effluents were collected from the top of a column, at room temperature into Teflon tubes using a fraction collector. The influent solutions were injected with a syringe pump at a pore-water velocity of $100 \mathrm{~mm} \mathrm{~d}^{-1}$. Because the sediment underneath waste tanks experienced a range of elevated temperatures, experiments were conducted at elevated and ambient temperatures. For the high-temperature tests, columns were set inside a water bath, with the temperature controlled at $70 \pm 0.5^{\circ} \mathrm{C}$. The ambient temperature tests were conducted at $21 \pm 1^{\circ} \mathrm{C}$.

Two sets of column experiments were conducted, using 50 and $250 \mathrm{~mm}$ tall columns. In the $50 \mathrm{~mm}$ tall set, nine pore volumes (PVs) of TWS were injected and followed by nine PVs of the leaching solution to test infiltration-induced colloid release. The leaching solution was a10-fold dilution of the soil water extract shown in Table 2. This solution was used to represent a mixture of native pore water from overlying uncontaminated soil and infiltrating rainfall water. Besides measuring $\mathrm{pH}$ and turbidity of the effluent 
fractions, precipitates contained in the plume front effluents were isolated for bulk chemical analyses (electron microprobe) and mineralogy identification (XRD). The precipitates were collected on filters $(0.25 \mu \mathrm{m})$, lightly rinsed with deionized water to remove excess soluble salts, and air-dried. In the $250 \mathrm{~mm}$ tall column set, only $6 \mathrm{PVs}$ of TWS were injected. In addition to measuring turbidity and $\mathrm{pH}$, concentrations of major cations were measured in these effluents.

Characterization of Effluent Solutions and Colloids. All measurements were conducted at room temperature. The $\mathrm{pH}$ measurements were obtained with a Corning Semi-Micro combination glass $\mathrm{pH}$ electrode. This electrode was connected to a Denver Instrument Model $225 \mathrm{pH} / \mathrm{ISE}$ meter. Calibrations were done with $\mathrm{pH}$ 4, 7, 10 (JT Baker), and 12.45 standards (Oakton). Recall that many of the experiments were conducted at high ionic strengths and elevated temperatures, whereas $\mathrm{pH}$ values were measured at room temperature. The reported $\mathrm{pH}$ values were intended for comparisons among the different systems rather than for inferring actual proton or hydroxyl activities under these extreme experimental conditions. Relative concentrations of suspended particles were measured by turbidity values (Hach Model 2100AN Turbidimeter, with a measurement range of 0 to 10,000 NTU (Nephelometric Turbidity Units)). The effluent fluids were ultrasonicated (Ultrasonic Cleaner, Cole Parmer 8892) for 10 minutes to disperse aggregates of particles before conducting turbidity measurements. Particle size distributions in the plume front effluent were measured using a centrifuge particle sizer (CPS, CPS Instrument, Inc.). Only the effluent fraction collected at the plume front contained enough particles for the particle size analyses.

Concentrations of major cations in effluents from the $250 \mathrm{~mm}$ tall columns were analyzed by ICP-OES (Thermo Jarell Ash Hi Res IRIS). Because many of these effluents contained colloids, and some of them formed after the effluents were collected, an aqua regia, hydrofluoric acid, and boric acid digestion was used to dissolve precipitates (19). The precipitates collected from effluent liquids were analyzed for their morphology 
(SEM), chemical compositions of individual particles [energy dispersive x-ray microanalysis (EDX)], mineralogy (XRD), and bulk chemical composition (electron microprobe). For the bulk chemical composition analyses, the air-dried precipitates were further dried at $110^{\circ} \mathrm{C}$, weighed, ignited at $925^{\circ} \mathrm{C}$, and weighed again to measure loss on ignition. Samples were fused with $\mathrm{Li}$ borate flux $\left(1: 1 \mathrm{Li}_{2} \mathrm{~B}_{4} \mathrm{O}_{7}: \mathrm{Li}_{2} \mathrm{BO}_{3}\right)$ in a $\mathrm{Pt}_{95} \mathrm{Au}_{5}$ crucible, in an oxidizing flame over an air-gas burner. Each sample was mixed with a Pt wire loop to make a bead, and the resulting bead was polished prior to determining major element concentrations using an electron microprobe $(20,21)$. Note that only the plumefront liquid contained enough mass of particles for the bulk chemical analyses.

\section{Results and Discussion}

Colloid Abundance in Effluents. The turbidity and $\mathrm{pH}$ breakthrough curves (BTC) under ambient $\left(21^{\circ} \mathrm{C}\right)$ and elevated $\left(70^{\circ} \mathrm{C}\right)$ conditions are presented in Figures 1 and $2 \mathrm{a}-\mathrm{b}$, for 50 and $250 \mathrm{~mm}$ tall columns, respectively. The turbidity and $\mathrm{pH}$ measurements were conducted as soon as effluent samples were collected. The vertical dashed line along the pore-volume axis in Figure $1 \mathrm{a}$ and $1 \mathrm{~b}$ denotes the time of switching injection solution from the TWS to the leaching solution. Through these BTCs, we see the effluent began emerging from a column after about 0.6 PV of TWS injection, as expected based on the calculated TWS displacement of the native sediment moisture (30\% initial saturation). The first effluent fraction for the $50 \mathrm{~mm}$ tall and the first 3 fractions for the $250 \mathrm{~mm}$ tall columns contained primarily the displaced native soil water, which were characterized by their $\mathrm{pH}$ values $\approx 8$ (the initial soil water $\mathrm{pH}$ ), and by their low salt concentrations (shown in figures $2 \mathrm{c}-\mathrm{h}$ ). Also, the first native soil water fractions have relatively higher turbidity values than the second fractions (visible in Figure 1), because of suspended disturbed native soil particles. The second effluent fractions exhibit influence from mixing of the displaced soil water with TWS, indicated by its increased ionic strength, and decreased $\mathrm{pH}$. The plume-front location can be determined by calculation of pore water 
displacement, and also by using the inflection point of the solution EC breakthrough, which indicates mixing of high-saline TWS with the displaced low salinity native soil water. The phenomenon of dramatic $\mathrm{pH}$ reduction at the plume front has been reported recently (13, 14) and will be discussed further in this paper.

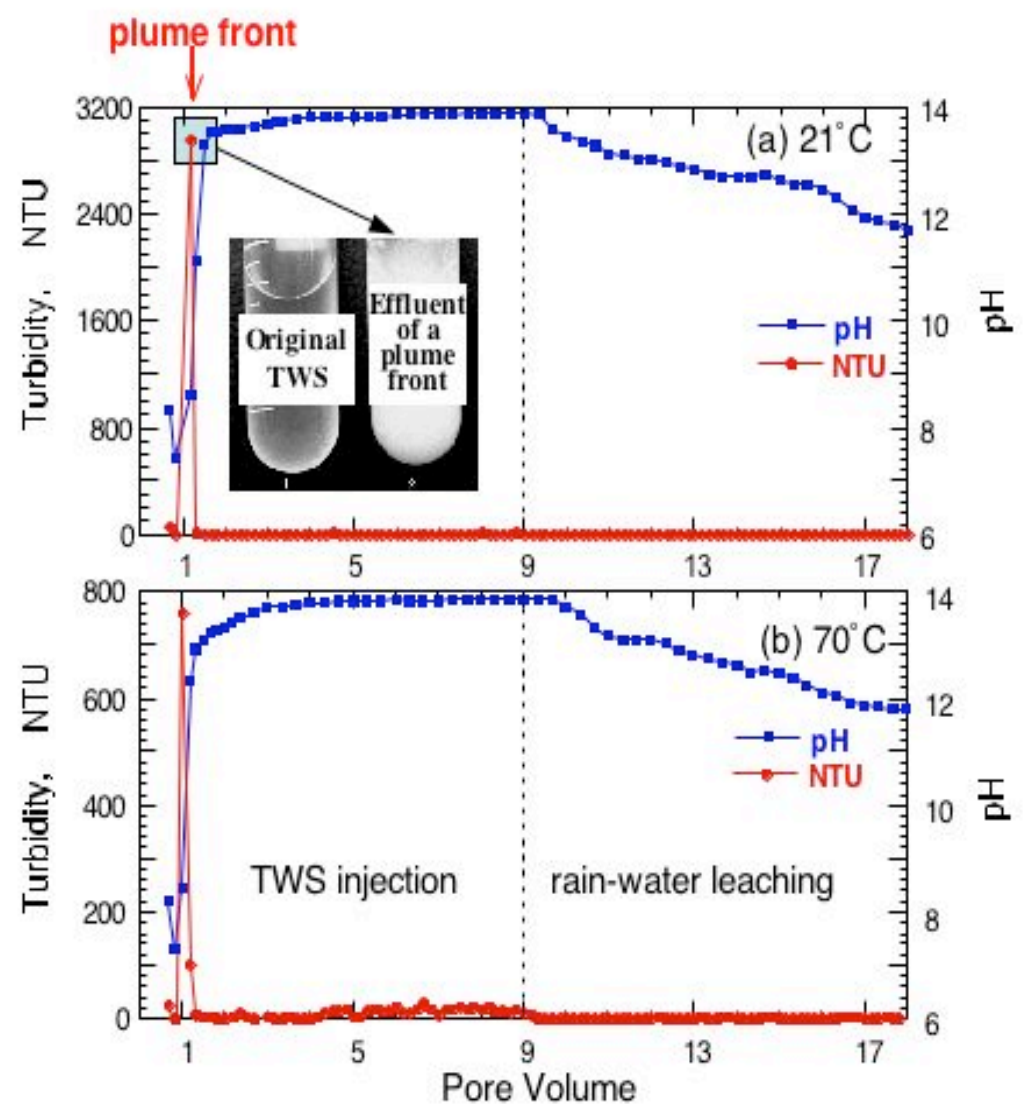

Figure 1. Turbidity and $\mathrm{pH}$ breakthrough curves from two $50 \mathrm{~mm}$ tall sediment columns at (a) $21^{\circ} \mathrm{C}$, and (b) $70^{\circ} \mathrm{C}$. Nine PVs of the TWS were injected, followed by nine PVs of simulated rainwater. The vertical dashed lines along the x-axes indicate times for switching of these two solutions. The inserted photograph provides a comparison between the clear influent TWS, and the milky plume front effluent. 


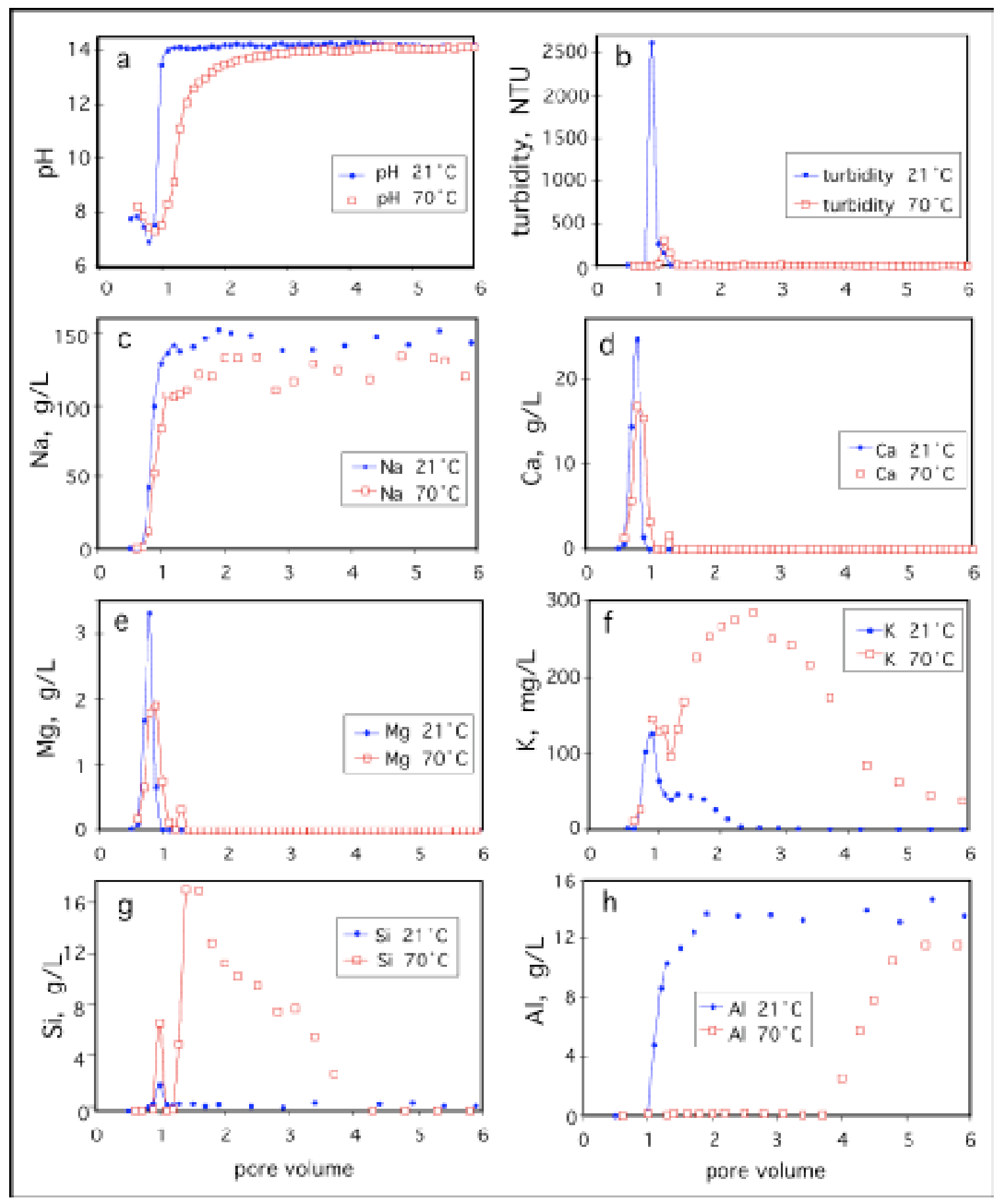

Figure 2. Breakthrough curves from two $250 \mathrm{~mm}$ tall columns $\left(21^{\circ} \mathrm{C}\right.$ and $\left.70^{\circ} \mathrm{C}\right)$. These breakthrough curves of $\mathrm{pH}$, turbidity, and the major cations were from six PVs of TWS injection. 
Figures 1 and $2 \mathrm{~b}$ show that an extremely high and narrow turbidity peak occurred at the plume front (at about $1 \mathrm{PV}$ ), indicating formation and transport of large quantities of suspended particles. As shown in the Figure 1a inserted picture, the plume front particle concentration was so high that the effluent looked like milk. The peak turbidity values under ambient temperature conditions were always higher than that under $70^{\circ} \mathrm{C}$. The lower turbidities (less colloids) at $70^{\circ} \mathrm{C}$ probably resulted from higher retention of $\mathrm{Al}$ within the column (see Fig. 2h), and from larger retention of Si-associated solid phases. The highest turbidity sample $(3,400 \mathrm{NTU})$ obtained in the $21^{\circ} \mathrm{C}$ effluents contained 3.0 mass $\%$ suspended solids. Particles were also detected within the plume body and the leaching stage. However, turbidity values of these later effluents were too low to be distinguished from zero on the linear axes used in Figures 1 and $2 \mathrm{~b}$. It should be noted that turbidity changed over time after collection of effluents within the plume body and the leaching stage. From the measurements over 60 days after the collection we found that turbidity generally increased, except for in the plume front fraction where it decreased due to flocculation/aggregation. The increased turbidity over time is caused by newly formed colloids that are not the focus of this study. The greater extent of postcollection particle formation in the effluents from the $70^{\circ} \mathrm{C}$ columns largely resulted from supersaturation with respect to various minerals (discussed later) upon cooling to room temperature. Although the emphasis of this paper is not on these later precipitated particles, we determined their chemical compositions and structures in order to gain a more complete understanding of the reactions occurring in the plume.

Dramatic $\mathrm{pH}$ reduction of the reacted TWS was observed in the plume-front region (Figure 1 and 2a), where the $\mathrm{pH}$ decreased from 14 to as low as 7. Clearly, simple mixing of the TWS ( $\mathrm{pH} 14$ ) with native sediment water ( $\mathrm{pH} 8$ ) could not result in $\mathrm{pH}$ values $<8$. This suggests that the reactions resulting in colloid formation at the plume front are related to the large $\mathrm{pH}$ reduction (discussed further in a later section). Although both $21^{\circ} \mathrm{C}$ and $70^{\circ} \mathrm{C}$ columns exhibited similar $\mathrm{pH}$ decreases at the plume front, the $\mathrm{pH}$ of 
effluents collected after the front exhibited significant temperature dependence. The $\mathrm{pH}$ quickly increased back to 14 for the room temperature condition, indicating that the reaction(s) causing $\mathrm{pH}$ reduction were slow relative to the supply of TWS. In contrast, the slower $\mathrm{pH}$ recovery under high-temperature conditions indicates that $\mathrm{pH}$-reducing reactions remained significant. These different $\mathrm{pH}$ responses are indicative of strongly temperature-dependent reactions. Dissolution of silicates in caustic solutions is both strongly temperature-dependent and $\mathrm{pH}$ neutralizing (22).

Colloids mobilization through leaching was expected because of the reacted sediment exposure to the much lower ionic strength solution. However, leaching did not mobilize significant amounts of colloids. Turbidity values in the leaching stage (measured immediately after an effluent sample was collected) were in the range of 0 to a few NTU (Figure 1). The lack of colloid mobilization during the leaching stage is probably related to the high ionic strength of the reacted leaching solution. The originally low ionic strength leaching solution became supersaturated in respect of various minerals (turbidity increased over time and mineral formation occurred over time after the effluents were collected). The original $\mathrm{pH}$ of the leaching solution was 7, but the effluent $\mathrm{pH}$ values became ranging from close to 14 to 12 after 8 pore volumes of leaching solution injection. The high ionic strengths suppress colloid dispersion. However, drainage of the leached column followed by rewetting with leaching solution might enhance displacement of colloids because advancing wetting fronts have been shown to be effective at colloid mobilization (23).

Chemical Composition of Effluents. Information on the chemical compositions of effluents helps in understanding the plume front processes and provides more perspective on how much transport is localized at the front. Major cation compositions of effluents from the $250 \mathrm{~mm}$ tall columns are presented in Figures 2c-h. These data are from analyses of acid-digested suspensions, such that concentrations represent sums of solution and suspended solid phases. Most notably, $\mathrm{Ca}^{2+}$ and $\mathrm{Mg}^{2+}$ were stripped off 
from cation exchange sites by the very high $\mathrm{Na}^{+}$concentrations in the invading waste solution (Figure 2c), leaving these divalent cations at extremely high concentrations within the front and practically undetectable later (Figures $2 \mathrm{~d}$ and $2 \mathrm{e}$ ). More $\mathrm{Na}^{+}$retardation at $70^{\circ} \mathrm{C}$ resulted from formation and retention of Na-Si-bearing minerals (sodium-cancrinite and sodium silicate) within the columns. The slightly higher retardation of $\mathrm{Ca}$ and $\mathrm{Mg}$ at $70^{\circ} \mathrm{C}$ may also have resulted from precipitation of $\mathrm{Ca} / \mathrm{Mg}$ bearing phases. The $\mathrm{K}^{+}$curves have a similar cation exchange peak localized at the plume front, followed by a broader period with elevated concentrations reflecting release from dissolution of soil minerals, especially at $70^{\circ} \mathrm{C}$. Although the localized Si peak at the plume front at $70^{\circ} \mathrm{C}$ remains to be explained, Si removal (Figure 2g) resulted from temperature- and $\mathrm{pH}$-dependent dissolution of silicate minerals in the sediment columns. Si became non-detectable at the later time (after $4 \mathrm{PV}$ ), caused probably by coating induced reduction of silicate dissolution surfaces, and continuous precipitation of more stable Si-bearing solids such as cancrinites. The Al BTCs (Figure $2 \mathrm{~h}$ ) showed temperature and $\mathrm{pH}$ dependence. At the elevated temperature, reduced $\mathrm{pH}$ values (relative to $\mathrm{pH}$ 14) of effluents were also observed after emergence of the plume front ( $\mathrm{pH}$ curves in Figure 2a), primarily because of silicate dissolution. Because of the reduced $\mathrm{pH}$ and dissolved $\mathrm{Si}$, Al precipitated and was retained within the column. After further permeation, Si dissolution rate dropped and $\mathrm{pH}$ increased to nearly the initial $\mathrm{pH}$ of the TWS, thus allowing most of the $\mathrm{Al}$ originally in the TWS $(0.80 \mathrm{M})$ to emerge in the effluent. At ambient temperature, most of the TWS $\mathrm{Al}$ emerged in the plume effluent solution because $\mathrm{pH}$ neutralization resulting from silicate dissolution was relatively weak. Aluminum precipitation at $21^{\circ} \mathrm{C}$ occurred largely at the plume front where $\mathrm{pH}$ reduction was significant. It should be noted that effluent $\mathrm{Al}$ concentrations never reached the initial concentration of the TWS of $0.80 \mathrm{M}$. This is because $\mathrm{Al}$ precipitated $\left(\mathrm{Al}(\mathrm{OH})_{3}\right.$ solubility is strongly $\mathrm{pH}$-dependent) and retained within the column. 
Chemical Composition of Bulk Precipitates. Precipitates collected from the plume front effluents of the $50 \mathrm{~mm}$ tall columns at two different temperatures were analyzed by electron microprobe. Concentrations of major cations and loss on ignition (primarily $\mathrm{H}_{2} \mathrm{O}$, $\mathrm{OH}^{-}, \mathrm{CO}_{3}{ }^{2-}, \mathrm{NO}_{3}{ }^{-}$, and $\mathrm{SO}_{4}{ }^{2-}$ ) are presented in Table 4. Values of loss on ignition were 46 and 42 mass $\%$ for 21 and $70^{\circ} \mathrm{C}$ systems, respectively. Calcium was the most abundant cation (27 to 31 mass \% as $\mathrm{CaO}$ ), and $\mathrm{Mg}$ concentrations were also high (5 to 4 mass \% as $\mathrm{MgO}$ ). Again $\mathrm{Ca}$ and $\mathrm{Mg}$ accumulated only within the narrow region of the moving plume front by cation exchange, displaced by $\mathrm{Na}(8 \mathrm{M})$ in the invading TWS, followed by precipitation of $\mathrm{Ca} / \mathrm{Mg}$ solids. The next most abundant cations within the plume-front precipitates were $\mathrm{Al}$ at ambient temperature, and $\mathrm{Si}$ at high temperature. Their precipitation at the plume front resulted from encountering reduced $\mathrm{pH}$. These results are consistent with data on total elemental concentrations in effluents presented in the previous section.

Table 4. Chemical compositions of bulk precipitates collected from plume front effluents

\begin{tabular}{|c|l|c|c|c|c|c|c|c|c|}
\hline \multicolumn{2}{|c|}{} & $\mathrm{SiO}_{2}$ & $\mathrm{Al}_{2} \mathrm{O}_{3}$ & $\mathrm{Fe}_{2} \mathrm{O}_{3}$ & $\mathrm{MgO}$ & $\mathrm{CaO}$ & $\mathrm{Na}_{2} \mathrm{O}$ & $\begin{array}{c}\text { Loss on } \\
\text { ignition }\end{array}$ & $\sum \%$ \\
\hline \multirow{2}{*}{$\begin{array}{c}\text { Mass } \\
\%\end{array}$} & $21^{\circ} \mathrm{C}$ & 0.34 & 18.18 & 0.04 & 5.38 & 26.88 & 0.46 & 45.90 & 97.18 \\
\cline { 2 - 10 } & $70^{\circ} \mathrm{C}$ & 18.73 & 0.60 & 0.36 & 4.02 & 31.36 & 2.28 & 42.10 & 99.44 \\
\hline
\end{tabular}

Morphology and Mineralogy of Colloids: The morphology, chemical composition, and mineralogy of plume-front colloids collected from the peak turbidity fraction are presented in Figure $3\left(21^{\circ} \mathrm{C}\right)$ and Figure $4\left(70^{\circ} \mathrm{C}\right)$. Figure 3a shows the typical morphology of colloids formed at ambient temperature. This image indicates that the nominally $1 \mu \mathrm{m}$ size is dominant in terms of mass, and nominally $0.1 \mu \mathrm{m}$ size is dominant in terms of numbers of particles. For the sample shown in Figure 3a, powder XRD analyses identified only calcite (Figure $3 b$ ), and the fine particles presented in Figure $3 a$ 
were amorphous. EDX analyses indicated that the individual larger particles in Fig. 3a consist of $\mathrm{Ca}-\mathrm{O}-\mathrm{C}$ (not shown), while the total area $(10 \mu \mathrm{m})$ analyses yielded $\mathrm{Ca}-\mathrm{Al}-\mathrm{Mg}$ O-C (Figure 3c). In another $21^{\circ} \mathrm{C}$ plume front sample, XRD patterns matched the spectra of calcium magnesium aluminum oxide carbonate hydrate $\left[(\mathrm{Ca}, \mathrm{Mg}) \mathrm{O}_{3} \cdot \mathrm{Al}_{2} \mathrm{O}_{3} \cdot \mathrm{CaCO}_{3} \cdot 11 \mathrm{H}_{2} \mathrm{O}\right\}$ (not shown). In contrast, the $70^{\circ} \mathrm{C}$ plume front colloids are very different in most respects from the $21^{\circ} \mathrm{C}$ colloids, except that $\mathrm{Ca}$ is also a major element. Figure $4 \mathrm{a}$ and $4 \mathrm{~b}$ show the overall morphology of the particles and the area-averaged chemical composition, respectively. The major elements of these colloids are Si-Ca-O-C. Figure 4a shows two types of morphologies: fine particles (Figure 4c) and larger hollow spheroids (Figure 4d). EDX data indicate that the fine particles are $\mathrm{CaCO}_{3}$-rich, and also contain small amounts of $\mathrm{Al}, \mathrm{Mg}, \mathrm{Na}, \mathrm{Si}$, and $\mathrm{S}$. The larger spheroids are predominantly $\mathrm{Si}-\mathrm{O}$, but also contain $\mathrm{Na}$ and $\mathrm{Mg}$. Like the ambient temperature colloids, XRD analyses from the $70^{\circ} \mathrm{C}$ samples identified only calcite. The Si-rich spheroidal aggregates were amorphous in TEM electron microdiffraction analyses as well.

We also studied the morphology, chemical composition and mineralogy of particles collected from the plume body and leaching stage effluents. We found that within the plume body effluents, cancrinite $\left[\mathrm{Na}_{8}\left(\mathrm{Al}_{6} \mathrm{Si}_{6} \mathrm{O}_{24}\right)\left(\mathrm{NO}_{3}\right)_{2} \cdot 4 \mathrm{H}_{2} \mathrm{O}\right]$ and zeolite $\left[\mathrm{Na}_{2} \mathrm{Al}_{2} \mathrm{Si}_{1.85} \mathrm{O}_{7.7} \cdot 5.1 \mathrm{H}_{2} \mathrm{O}\right]$ were the major mineral phases under both temperatures, with larger quantity of precipitates under $70^{\circ} \mathrm{C}$. This is because of higher Si concentrations from higher silicate dissolution rates at $70^{\circ} \mathrm{C}$. Particles collected from the leaching stages under the two temperatures were very different. At $70^{\circ} \mathrm{C}$, the same cancrinite and zeolite found in the plume body were also identified in leaching stage. However, at $21^{\circ} \mathrm{C}$, bayerite and calcite were the major mineral phases. Unlike the plume front colloids (dominantly amorphous/poorly crystallized, and submicron sizes), these precipitates were well crystallized and larger (up to about $5 \mu \mathrm{m}$ ). The majority of these formed after the effluents were collected. Details of these results are not presented because this paper is focused on the plume fronts. 


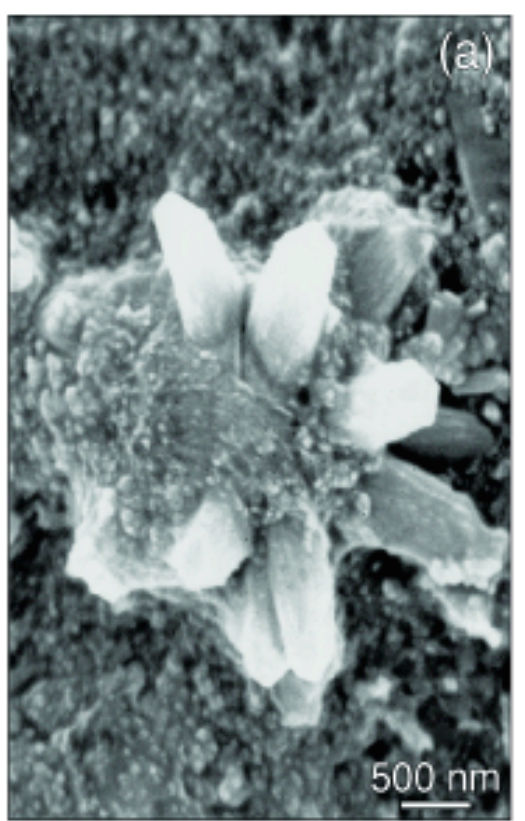

Figure 3
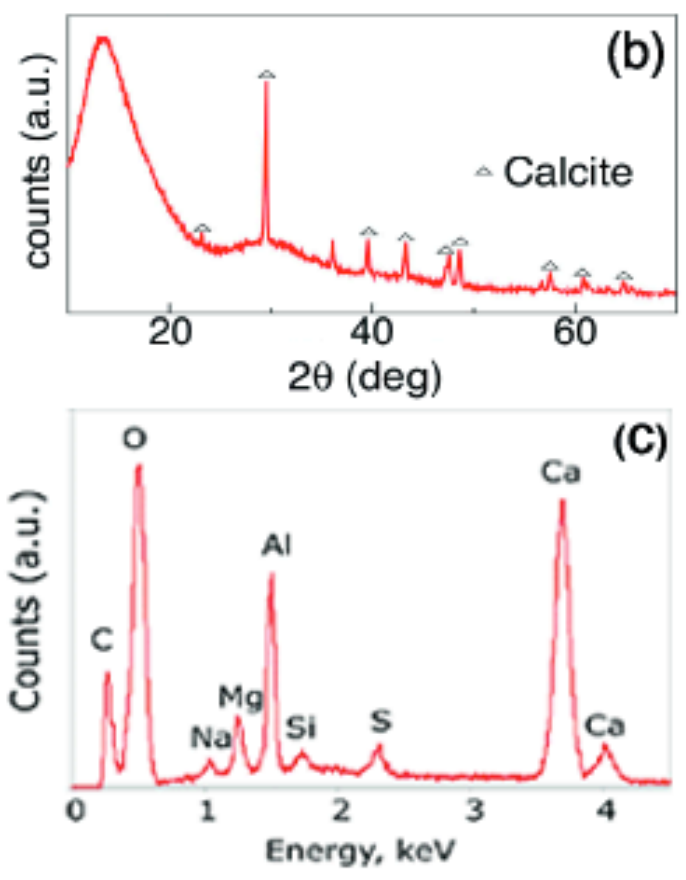

Figure 3. (a) SEM microphotograph of plume-front colloids at $21^{\circ} \mathrm{C}$ comprised of fine amorphous particles, and larger crystals. (b) XRD pattern of the bulk precipitates, indicating that calcite is the only crystalline phase. (Note: the large unmarked peak is the result of the sample holder used.) (c) Chemical composition from total area $\left(10 \mu \mathrm{m}^{2}\right)$ analysis. 


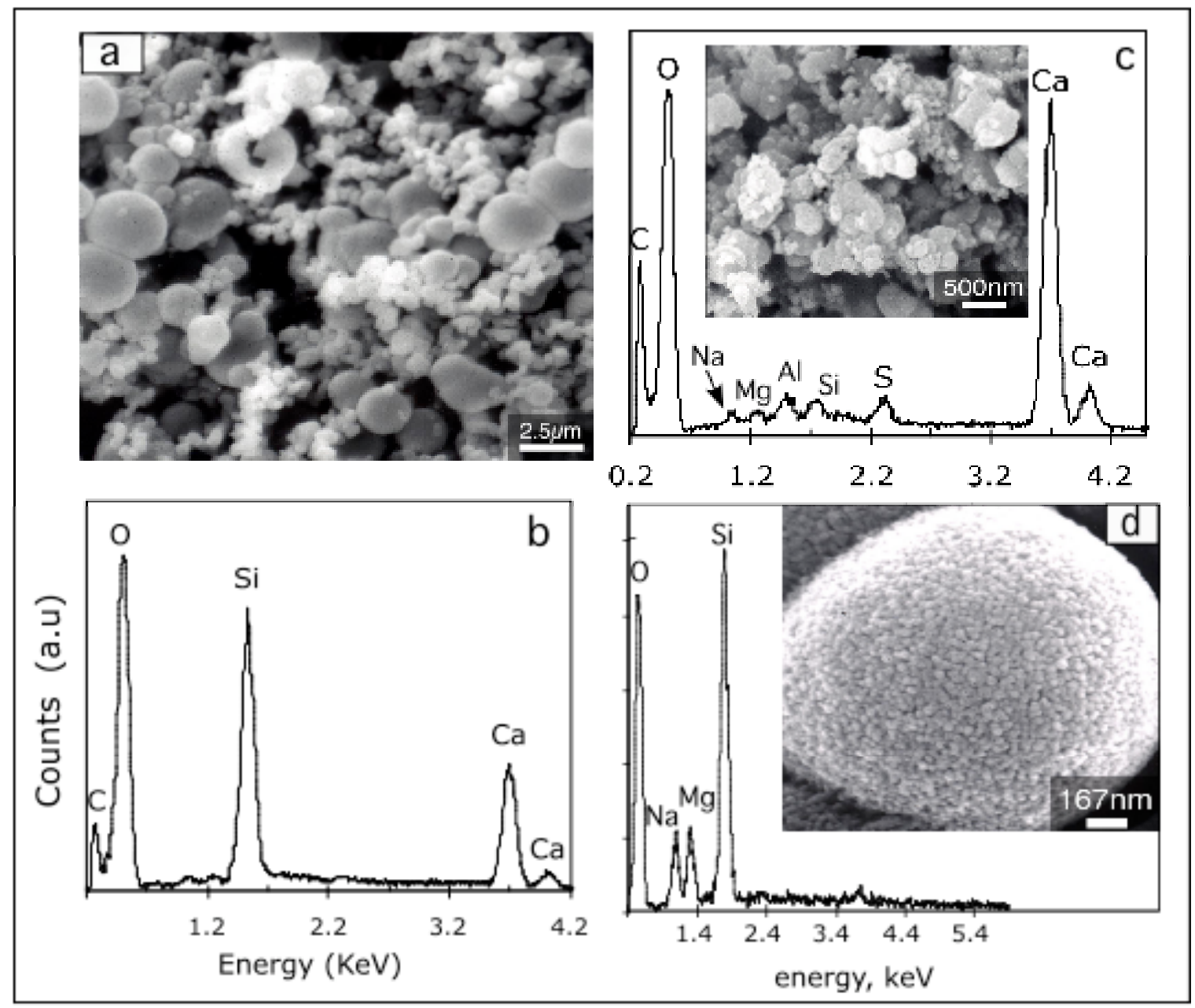

Figure 4. Plume-front colloids at $70^{\circ} \mathrm{C}$. (a) SEM image of a bulk sample. (b) EDX of the bulk sample. (c) The fine particles contained predominantly $\mathrm{Ca}-\mathrm{C}-\mathrm{O}$, and calcite was identified in this sample. (d) Spheres are aggregates of fine amorphous Si-O-(Na,Mg) particles. 
Particle Size. Although the turbidity data presented in Figures 1 and $2 \mathrm{~b}$ were measured as soon as an effluent fraction was collected, the SEM and XRD samples were prepared about 4 weeks later. This time lapse and equilibration with ambient temperature contributed to particle formation in effluents from the $70^{\circ} \mathrm{C}$ columns. Thus, the amorphous, hollow silicate spheres (Figures $4 \mathrm{a}$ and $4 \mathrm{~d}$ ) likely grew and aggregated after collection of the effluent. The particle size measurements obtained on freshly collected effluent suspensions are presented in Figure 5, only for the ambient temperature plume front colloids. Because these measurements must be done at ambient temperature, samples collected from the $70^{\circ} \mathrm{C}$ column would be influenced by post-sampling precipitation. The particle size analyses are from duplicate samples, and expressed in terms of relative masses, relative numbers, and relative surface areas, assuming a density of $2.7 \mathrm{~g} \mathrm{~cm}^{-3}$ and spherical shape. In terms of relative mass (Figure $5 \mathrm{a}$ ), over $90 \%$ of the mass is associated with colloids in the size range of 0.5 to $2.3 \mu \mathrm{m}$, with the highest contribution by about $1.0 \mu \mathrm{m}$ sized particles. In terms of number (Figure $5 \mathrm{~b}$ ), the large contribution is by the small particles in the size range of 30 to $100 \mathrm{~nm}(30 \mathrm{~nm}$ is the resolution limit of the CPS). In terms of surface area (Figure $5 \mathrm{c}$ ), over $90 \%$ of the total surface-area is associated with colloids in the size range of 0.3 to $2.0 \mu \mathrm{m}$. It is interesting to note that although the $<0.1 \mu \mathrm{m}$ fraction is dominant in terms of particle numbers, the nominally $1 \mu \mathrm{m}$ fraction is dominant in terms of not only mass, but surface area as well. 

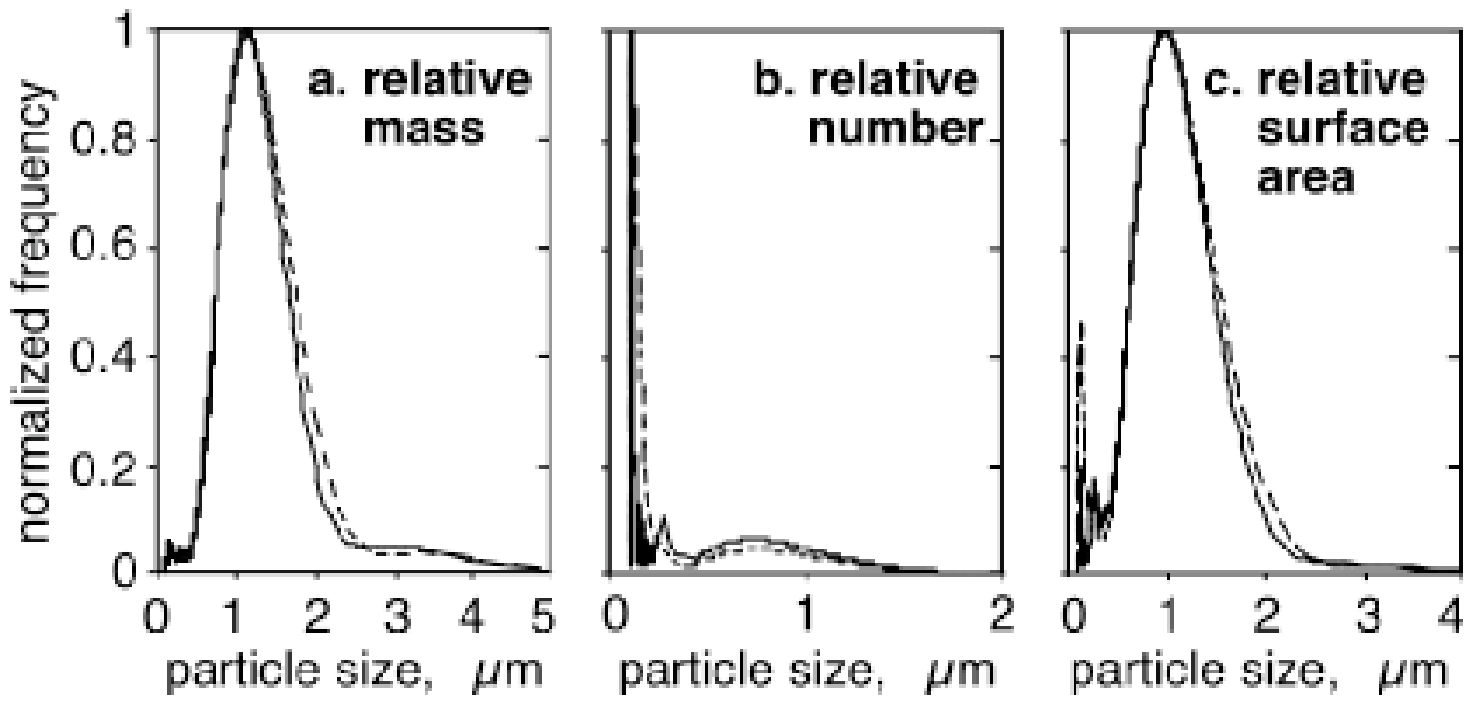

Figure 5. Size distribution of plume front colloids at $21^{\circ} \mathrm{C}$, presented in terms of (a) relative particle mass, (b) relative particle number, and (c) relative surface area. The particle density was assumed to be $2.7 \mathrm{~g} \mathrm{~cm}^{-3}$, and the shape was assumed to be spherical. The two sets of curves are duplicate samples of the plume front fraction.

Mechanisms Responsible for Colloid Formation at the Plume Front. The coupled transport and geochemical reactions during the tank leakage process are complex, and our understanding of these reactions and processes is still incomplete. Based on our limited experimental data, the likely geochemical reactions controlling colloid formation at the plume front are summarized in Table 5. Cation exchange (eq 1), with $\mathrm{Na}^{+}$replacing $\mathrm{Ca}^{2+}$ and $\mathrm{Mg}^{2+}$ from the cation exchange sites of the sediment, was the key process contributing to this plume front phenomenon. The cation exchange reaction was rapid and complete. At the same time, transport kept the exchanged divalent cations within the moving-front of the waste plume, where $\mathrm{Ca}^{2+} / \mathrm{Mg}^{2+}$ accumulated to elevated levels. The measured $\mathrm{Ca}^{2+} / \mathrm{Mg}^{2+}$ concentrations in the plume front of the $250 \mathrm{~mm}$ column were as high as $0.61 \mathrm{M} / 0.14 \mathrm{M}$ for $21^{\circ} \mathrm{C}$, and $0.38 \mathrm{M} / 0.07 \mathrm{M}$ for $70^{\circ} \mathrm{C}$ (Figures $2 \mathrm{~d}-\mathrm{e}$ ), and 1.2 $\mathrm{M} / 0.4 \mathrm{M}$ for a 2 meter tall column at $70^{\circ} \mathrm{C}(13)$. Supersaturation of these divalent cations 
with respect to a number of $\mathrm{Ca}^{2+} / \mathrm{Mg}^{2+}$-bearing minerals caused their rapid precipitation as well as precipitation of amorphous phases. Calcite (eq 2) was identified under both temperatures. Although dolomite and brucite (eqs 3 and 4) were not detected, we speculate that they could have formed in minor quantities. Calcium magnesium aluminum oxide carbonate hydrate and bayerite were identified (eqs 5 and 6), however in most of the analyses, amorphous phases containing Ca-Mg-Al-O-C were common in ambient temperature samples. Temperature is an important factor controlling the chemical composition of the colloid phases in these caustic plumes, primarily through affecting silicate dissolution rate, and consequently aqueous $\mathrm{Si}$ concentration, $\mathrm{pH}$, and in turn aqueous $\mathrm{Al}$ concentration. At ambient temperature, the concentration of the dissolved $\mathrm{Si}$ was not high enough to co-precipitate with much of the $\mathrm{Al}(0.8 \mathrm{M})$ initially contained in the TWS, and the solution pH was high enough to keep most of this Al in the solution as $\mathrm{Al}(\mathrm{OH})_{4}{ }^{-}$. Therefore, we saw high concentrations of Al-rich particles at the plume front only under the ambient temperature. Because of the extreme alkalinity of the initial TWS $(\mathrm{pH} \geq 14)$, dissolution of primary silicates in the sediment was significant, especially under elevated temperatures. Some of the dissolved Si was advected with the plume front, and after encountering the reduced $\mathrm{pH}$ at the plume front, it precipitated forming the colloidal Si phase (eq 7). Amorphous sodium silicate (eq 7) was abundant within the $70^{\circ} \mathrm{C}$ samples. Although cancrinite/zeolites precipitates were identified as the major secondary phases in plume bodies under both temperatures, they were not detected at the plume front. 
Table 5. Geochemical reactions within plume front

\begin{tabular}{|lc|c|}
\hline \multicolumn{1}{|c|}{ Possible plume front reactions } & $\begin{array}{l}\text { Log } \mathrm{K} \\
\left(25^{\circ} \mathrm{C}\right)\end{array}$ \\
\hline $\mathrm{Na}^{+}+1 / 2 \mathrm{Ca} / \mathrm{Mg}-\mathrm{X}=\mathrm{Na}-\mathrm{X}+1 / 2 \mathrm{Ca}^{2+} / \mathrm{Mg}^{2+}$ & $(1)$ & $-0.4^{\mathrm{a}} /-0.3^{\mathrm{a}}$ \\
\hline $\mathrm{Ca}^{2+}+\mathrm{HCO}_{3}{ }^{-}=\mathrm{CaCO}_{3}($ Calcite $)+\mathrm{H}^{+}$ & $(2)$ & $-1.85^{\mathrm{b}}$ \\
\hline $\mathrm{Ca}^{2+}+\mathrm{Mg}^{2+}+2 \mathrm{HCO}_{3}{ }^{-}=\mathrm{CaMg}\left(\mathrm{CO}_{3}\right)_{2}($ Dolomite $)+2 \mathrm{H}^{+}$ & $(3)$ & $-3.66^{\mathrm{b}}$ \\
\hline $\mathrm{Mg}^{2+}+2 \mathrm{H}_{2} \mathrm{O}=\mathrm{Mg}(\mathrm{OH})_{2}\left(\mathrm{Brucite}+2 \mathrm{H}^{+}\right.$ & $(4)$ & $-16.79^{\mathrm{b}}$ \\
\hline $2 \mathrm{Al}(\mathrm{OH})_{4}{ }^{-}+4(\mathrm{Ca}, \mathrm{Mg})^{2+}+\mathrm{CO}_{3}{ }^{2-}+9 \mathrm{H}_{2} \mathrm{O}=$ & $40.35^{\mathrm{c}}$ \\
{$\left[(\mathrm{Ca}, \mathrm{Mg}){ }_{3} \cdot \mathrm{Al}_{2} \mathrm{O}_{3} \cdot \mathrm{CaCO}_{3} \cdot 11 \cdot \mathrm{H}_{2} \mathrm{O}+4 \mathrm{H}^{+}\right.$} & $(5)$ & \\
\hline $\mathrm{Al}(\mathrm{OH})_{4}{ }^{-}=\mathrm{Al}(\mathrm{OH})_{3}\left(\mathrm{Bayerite}+\mathrm{OH}^{-}\right.$ & $(6)$ & $8.36^{b}$ \\
\hline $\mathrm{H}_{2} \mathrm{SiO}_{4}{ }^{-2}+2 \mathrm{Na}^{+}=\mathrm{Na}_{2} \mathrm{SiO}_{3}$ (Sodium metasilicate) $+\mathrm{H}_{2} \mathrm{O}$ & $(7)$ & $0.81^{\mathrm{d}}$ \\
\hline
\end{tabular}

${ }^{\text {a. }}$ Appelo and Postma (24); ${ }^{\text {b. }}$ Minteq (25); ${ }^{\text {c. }}$ Wan et al (14); ${ }^{\text {d. }}$ LLNL (26).

Implications for Radionuclide Transport. This study revealed a striking phenomenon during leakage of a highly saline-caustic waste solution into sediments; colloid formation within a narrow zone at the moving plume front. Transport of suspended colloids was thousands of times higher in this narrow plume front than in the plume body and the leaching stage. The newly formed plume front colloids were primarily in the size range of 0.3 to $2.0 \mu \mathrm{m}$, predominantly $\approx 1.0 \mu \mathrm{m}$, and poorly crystallized. The major chemical compositions of these colloids were $\mathrm{Ca}-\mathrm{Mg}-\mathrm{Al}-\mathrm{C}-\mathrm{O}$ under ambient temperature, and $\mathrm{Ca}-$ $\mathrm{Mg}-\mathrm{Si}-\mathrm{C}-\mathrm{O}$ at elevated temperature. Rapid and completed cation exchange of $\mathrm{Na}^{+}$ replacing $\mathrm{Ca}^{2+}$ and $\mathrm{Mg}^{2+}$ from the sediments, coupled with flow of the infiltrating waste solution enriched these divalent cations within the moving plume front. Subsequent precipitation of colloids containing these divalent cations released protons and reduced the plume front $\mathrm{pH}$ to as low as neutral. This substantially reduced $\mathrm{pH}$ in turn promoted precipitation of Al- and Si-bearing minerals and amorphous phases. This plume front colloid generation phenomenon can occur under a wide range of conditions, with the only necessary condition being that of high $\mathrm{Na}^{+}$concentration in the waste plume. Because of 
the large amounts of particles generated at the front, this phenomenon could significantly affect the fate and transport of the contaminant trace elements contained within the waste plume. Depending on the chemical properties of the individual trace element, radionuclide or toxic metal, it can co-precipitate with or adsorb onto the plume front colloids. For example, $\mathrm{U}$ sorption and coprecipitation on calcite (27) may be important in some contaminated sediments at the Hanford Site because high levels of $U$ are contained in some tank wastes and because calcite is the major plume front colloid phase.

\section{Acknowledgments}

We thank 3 anonymous reviewers for their helpful comments. This work was carried out under U.S. Department of Energy Contract No. DE-AC03-76SF-00098. Funding was from the Basic Energy Science program and the Environmental Management Science Program of the Office of Science, U.S. Department of Energy.

Key Words: waste plume front; reaction front; tank leakage; cation exchange; colloid formation; Hanford Site

Brief: Most of the mobile colloid inventory during infiltration of saline waste solution is found at the plume front. 


\section{Literature Cited}

1. Riley, R. G.; Zachara, J. M.; Wobber, F. J. Chemical contaminants on DOE lands and selection of contaminant mixtures for subsurface science research. DOE Office of Energy Research Subsurface Science Program, DOE/ER-0547T, 1992.

2. U.S. Department of Energy. Vadose zone characterization project at the Hanford Tank Farms-SX Tank Farm. DOE/ID/12584-268, U. S. Department of Energy: Grand Junction, CO, 1996.

3. Ward, A. L.; Gee, G. W.; White, M. D. A comprehensive analysis of contaminant transport in the vadose zone beneath tank SX-109. PNNL-11463, Pacific Northwest National Laboratory: Richland, WA, 1997.

4. Agnew, S. F.; Boyer, J.; Corbin, R. A.; Duran, T. B.; Fitzpatrick, J. R.; Jurgensen, K. A.; Ortiz, T. P.; Young, B. L. Hanford tank chemical and radionuclide inventories: HDW Model Rev. 3. LA-UR-96-858, Los Alamos National Laboratory, Los Alamos, NM, 1996.

5. Jones, T. E.; MacLean, G. T. Inventory estimates for single-shell tank leaks in S and SX tank farms. RPP-6285, CH2MHILL Hanford Group, Inc.: Richland, WA, 2000.

6. Lichtner, P. C.; Felmy, A. Estimation of Hanford SX tank waste compositions from historically derived inventories. Computers \& Geosciences 2002, 29, 371-383.

7. Buddemeier, R. W.; Hunt, J. R. Transport of colloidal contaminants in groundwater: radionuclide migration at the Nevada Test Site. Appl. Geochem. 1988, 3, 535-548.

8. Ryan, J. N.; Elimelech, M. Colloid mobilization and transport in groundwater. Colloids and Surfaces 1996, 107, 1-56.

9. McKinley, J. P.; Zeissler, C. J.; Zachara, J. M.; Serne, R. J.; Lindstrom, R. M.; Schaef, R. T.; Orr, R. D. Distribution and retention of Cs-137 in sediments at the Hanford Site, Washington. Environ. Sci. Technol. 2001, 35, 3433-3441. 
10. Zachara, J. M.; Smith, S. C.; Liu, C.; McKinley, J. P.; Serne, R. J.; Gassman, P. L. Sorption of $\mathrm{Cs}^{+}$to micaceous subsurface sediments from the Hanford site, USA. Geochim. Cosmochim. Acta 2002, 66, 193-211.

11. Bickmore, B. R.; Nagy, K. L.; Young, J. S.; Drexler, J. W. Nitrate-cancrinite precipitation on quartz sand in simulated Hanford tank solutions. Environ. Sci. Technol. 2001, 35, 4481-4486.

12. Chorover, J.; Choi, S.; Amistadi, M. K.; Karthikeyan, K. G.; Crosson, G.; Mueller, K. T. Linking cesium and strontium uptake to kaolinite weathering in simulated tank waste leachate. Environ. Sci. Technol. 2003, 37, 2200-2208.

13. Wan, J.; Tokunaga, T. K.; Larsen, J. T.; Serne, R. J. Geochemical evolution of highly alkaline and saline tank waste plumes during seepage through vadose zone sediments. Geochim. Cosmochim. Acta 2004a, 68, 491-502.

14. Wan, J; Larsen, J. T.; Tokunaga, T. K.; Zheng, Z. pH neutralization and zonation in alkaline-saline tank waste plumes. Environ. Sci. Technol. 2004b, 38, 1321-1329.

15. Liu, C.; Zachara, J. M.; Smith, S. C. A cation exchange model to describe $\mathrm{Cs}^{+}$sorption at high ionic strength in subsurface sediments at Hanford site, USA. Contaminant Hydrology 2004, 68, 217-237.

16. Lichtner, P. C.; Yabusaki, S.; Pruess, K.; Steefel, C. Role of competitive cation exchange on chromatographic displacement of cesium in the vadose zone beneath the Hanford S/SX Tank Farm. Vadose Zone J. 2004, 3, 203-219.

17. Flury, M.; Mathison, J. B.; Harsh, N. J. In situ mobilization of colloids and transport of cesium in Hanford srdiments. Environ. Sci. Technol. 2002, 36, 5335-5341.

18. Serne, R. J.; LeGore, V. L.; Last, G. V.; Schaef, H. T.; O’Hara, M. J.; Smith, S. C.; Bjornstad, B. N.; Brown, C. F.; Lindenmeier, C. W.; Williams, B. A.; Parker, K. E.; Zachara, J. M.; Lanigan, D. C.; Kutnyakov, I. V.; Burke, D. B.; Horton, D. G.; Serne, J. N.; Clayton, R. E.; Mitroshkov, A. V. Characterization of Uncontaminated Sediments 
from the Hanford Reservation-RCRA Borehole Core Samples and Composite Samples. DE-AC06-76RLO 1830, Pacific Northwest National Laboratory: Richland, WA, 2001.

19. Hossner L. R. Dissolution for total elemental analysis. Chapter 3, in Methods of Soil Analysis, Part 3- Chemical Methods, Number 5 in Soil Science Society America Book Series, Am. Soc. Agron., Madison, WI 1996, 49-64, 1996.

20. Couture, R. A. An improved fusion technique for major-element analysis by XRF. Advances in X-Ray Analysis 1989, 32, 233-238.

21. Couture, R. A.; Smith, M. S.; Dymek, R. F. X-ray fluorescence analysis of silicate rocks using fused glass discs and a side-window Rh source tube- Accuracy, precision, and reproducibility. Chemical Geology 1993, 110, 315-328.

22. Rimstidt J. D.; Barnes H. L. The kinetics of silica-water reactions. Geochim. Cosmochim. Acta 1980, 44, 1683-1699.

23. Saiers, J. E.; J. J. Lenhart. Colloid mobilization and transport within unsaturated porous media under transient-flow conditions. Water Resour. Res. 2003, 39, 1019.

24. Appelo, C. A. J.; Postma, D. Geochemistry, groundwater and pollution. A. A. Balkema, Rotterdam, 1996.

25. Allison, I. D.; Brown, D. S.; Novo-Gradac, K. J. MINTEQA2/PRODEFA2: A geochemical assessment model for environmental systems. Version 3.0. Environmental Research Laboratory, Office of Research and development, U. S. Environmental Protection Agency, 1990.

26. Wolery, T. J. Calculation of chemical equilibrium between aqueous solution and minerals. The EQ3/6 software package: Lawrence Livermore National Laboratory, UCRL-52658, Livemore, 1979.

27. Reeder, R. J.; Nugent, M.; Tait, C. D.; Morris, D. E.; Heald, S. M.; Beck, K. M.; Hess, W. P.; Lanzirotti, A. Coprecipitation of uranium(VI) with calcite: XAFs, micro-XAS, and luminescence characterization. Geochim. Cosmochim. Acta 2001, 65, 3491-3503. 


\section{Figure Captions}

Figure 1. Turbidity and $\mathrm{pH}$ breakthrough curves from two $50 \mathrm{~mm}$ tall sediment columns at (a) $21^{\circ} \mathrm{C}$, and (b) $70^{\circ} \mathrm{C}$. Nine PVs of the TWS were injected, followed by nine PVs of simulated rainwater. The vertical dashed lines along the $\mathrm{x}$-axes indicate times for switching of these two solutions. The inserted photograph provides a comparison between the clear influent TWS, and the milky plume front effluent.

Figure 2. Breakthrough curves from two $250 \mathrm{~mm}$ tall columns $\left(21^{\circ} \mathrm{C}\right.$ and $\left.70^{\circ} \mathrm{C}\right)$. These breakthrough curves of $\mathrm{pH}$, turbidity, and the major cations were from six PVs of TWS injection.

Figure 3. (a) SEM microphotograph of plume-front colloids at $21^{\circ} \mathrm{C}$ comprised of fine amorphous particles, and larger crystals. (b) XRD pattern of the bulk precipitates, indicating that calcite is the only crystalline phase. (Note: the large unmarked peak is the result of the sample holder used.) (c) Chemical composition from total area $\left(10 \mu \mathrm{m}^{2}\right)$ analysis.

Figure 4. Plume-front colloids at $70^{\circ} \mathrm{C}$. (a) SEM image of a bulk sample. (b) EDX of the bulk sample. (c) The fine particles contained predominantly $\mathrm{Ca}-\mathrm{C}-\mathrm{O}$, and calcite was identified in this sample. (d) Spheres are aggregates of fine amorphous $\mathrm{Si}-\mathrm{O}-(\mathrm{Na}, \mathrm{Mg})$ particles.

Figure 5. Size distribution of plume front colloids at $21^{\circ} \mathrm{C}$, presented in terms of (a) relative particle mass, (b) relative particle number, and (c) relative surface area. The particle density was assumed to be $2.7 \mathrm{~g} \mathrm{~cm}^{-3}$, and the shape was assumed to be spherical. The two sets of curves are duplicate samples of the plume front fraction. 